\title{
UWAGI O SPECYFICE AUTORSKICH DÓBR OSOBISTYCH ORAZ KONCEPCJI ICH OCHRONY (NA PRZYKŁADZIE PRAWA DO AUTORSTWA UTWORU)
}

I. W polskiej literaturze dominuje stanowisko, że wszystkie autorskie dobra osobiste przysługujące twórcy są objęte pojęciem „twórczość naukowa i artystyczna" wymienionym $\mathrm{w}$ art. 23 k.c. ${ }^{1}$, a więc są wycinkiem dóbr osobistych powszechnego prawa cywilnego ${ }^{2}$. W mniejszości pozostaja poglądy o odrębności autorskich dóbr osobistych ${ }^{3}$. Ponadto przyjmuje się, że dobra osobiste są wartościami niemajątkowymi ściśle związanymi z osobowością człowieka, i dominuje pogląd, że cywilnoprawną ochronę tych dóbr należy oprzeć na konstrukcji prawa podmiotowego ${ }^{4}$. W zdecydowanej przewadze wobec koncepcji jednego prawa osobistości jest pogląd o wielości praw podmiotowych osobistych $^{5}$. Koncepcję jednego prawa osobistości na gruncie polskiego systemu niektórzy autorzy uznają za pozbawioną praktycznej doniosłości 6 .

Warto nadmienić, że poglądy krytyczne wobec koncepcji ochrony dóbr osobistych za pomoca konstrukcji praw podmiotowych wyrażano w polskiej literaturze jeszcze pod rządami dawniej obowiązujacego prawa cywilnego. Twierdzono, że normy tego prawa nie tworzą systemu praw podmiotowych, lecz określają wyłącznie normy postępowania. W związku z tym prawa osobistości nie sa prawami podmiotowymi, lecz dowodem uznania w ustroju prawnym doniosłego stanowiska człowieka. Podkreślano, że ochrona pewnej sytuacji prawnej nie wymaga wyposażenia ,podmiotu tej sytuacji” w prawo podmiotowe, gdyż wystarczy, że wspomniana ochrona ma dla tego podmiotu znaczenie „w jakiejkolwiek dziedzinie życia społecznego"”.

Dorobek nauki polskiej w zakresie problematyki dóbr osobistych prawa powszechnego oraz ich ochrony, a także dotyczący autorskich dóbr osobistych i autorskich praw osobistych jest ogromny. W literaturze pojawiają się różne

${ }^{1}$ Ustawa z 23 kwietnia 1964 r. - Kodeks cywilny, t.jedn.: Dz. U. 2014, poz. 21 ze zm.

${ }^{2}$ Por. E. Wojnicka, B. Giesen, w: System prawa prywatnego, t. 13: Prawo autorskie, red. J. Barta, Warszawa 2013, s. 285 oraz literatura tam cytowana.

${ }^{3}$ Ibidem oraz literatura tam cytowana.

${ }^{4}$ M. Pazdan, w: System prawa prywatnego, t. 1: Prawo cywilne - część ogólna, red. M. Safjan, Warszawa 2007, s. 1149 oraz cytowani tam autorzy: F. Zoll, S. Grzybowski, A. Szpunar, Z. Radwański.

${ }^{5}$ Por. J. Chaciński, Prawa podmiotowe a ochrona dóbr osobistych, Lublin 2004, s. 142-143.

${ }^{6}$ M. Lijowska, Koncepcja ogólnego prawa osobistości $w$ niemieckim i polskim prawie cywilnym, „Kwartalnik Prawa Prywatnego” 10, 2001, z. 4, s. 795.

${ }^{7}$ Por. np. J. Chaciński, op. cit., s. 143-144 oraz literatura tam cytowana. 
poglądy i broni się odmiennych koncepcji dotyczącyh wspomnianych kwestii. Stosujacc duże uogólnienie tych poglądów, można stwierdzić, że prawa osobiste odpowiadające poszczególnym dobrom osobistym uznaje się za nieodłącznie związane z człowiekiem, niezbywalne, niemajątkowe i bezwzględne, a zatem skuteczne względem wszystkich ${ }^{8}$. Każde dobro osobiste człowieka mieszczace się w zakresie art. 23 k.c. uważa się za chronione odrębnym prawem podmiotowym bezwzględnym oraz dominuje pogląd, że autorskie dobra osobiste należą do dóbr osobistych mieszczących się w zakresie tego przepisu, a więc sa także dobrami osobistymi powszechnego prawa cywilnego ${ }^{9}$. Autorskie prawa osobiste (jak i majątkowe) na autorskich dobrach osobistych charakteryzuje się jako prawa bezwzględne, a więc skuteczne wobec wszystkich ${ }^{10}$.

Celem niniejszego opracowania jest próba wykazania, że autorskie dobra osobiste, a nie autorskie prawa osobiste, o których mowa w art. 16 pr.aut. ${ }^{11}$, powinny być przedmiotem ochrony prawa autorskiego. Autorskie dobra osobiste jako związane ze statusem twórcy utworu nie sa dobrami osobistymi w rozumieniu art. 23 k.c. Status twórcy nie jest bowiem atrybutem każdego człowieka. Podjęta zostanie także próba uzasadnienia stanowiska, że status twórcy, kwalifikowany przez autorstwo utworu, nie powinien być chroniony w ramach konstrukcji prawa podmiotowego, ponieważ to prawo może przysługiwać tylko podmiotowi prawa cywilnego, a w prawie autorskim ochronie podlega także status „twórcy zmarłego”. To stanowisko opiera się także na argumencie, że autorstwo utworu jest efektem wolności tworzenia. Możność tworzenia utworu nie jest wynikiem realizacji prawa podmiotowego, gdyż każdemu wolno podjać się lub też nie tworzenia utworu. Status twórcy utworu, czyli „ojcostwa utworu”, jest chroniony prawem autorskim, ponieważ to prawo respektuje kształtowany w społeczeństwie przez wieki pogląd o konieczności ochrony wspomnianego statusu, przejawiającego intelektualną więź twórcy z utworem. Piętno osobowości twórcy tkwi w utworze w formie usamodzielnionej w tym znaczeniu, że przez tworzenie i stworzenie utworu twórca nie traci swojej osobowości, tylko ja „odzwierciedla” w utworze. Autorstwo świadczy o ojcostwie utworu, ale także utwór, przez tkwiący w nim „odzwierciedlony element osobowości, twórcy", świadczy o pochodzeniu od danego twórcy. Wydaje się, że do ochrony tej więzi, a więc w istocie statusu twórcy, nie nadaje się koncepcja prawa podmiotowego ze względu na konstrukcyjny wymóg istnienia podmiotu prawa cywilnego. Do wzięcia udziału w dyskusji na temat autorskich prawa osobistych skłania brzmienie art. 16 pr.aut. Według tego przepisu „autorskie prawa osobiste chronią [...] więź twórcy z utworem, a w szczególności prawo do: 1) autorstwa utworu [...]”. Rozmiary opracowania nie pozwalaja na wypowiedzenie się o konstrukcji wszystkich „pojedynczych” osobistych pra-

${ }^{8}$ M. Pyziak-Szafnicka, w: System, t. 1, s. 719.

${ }_{9}^{9}$ Ibidem, s. 719-720 oraz literatura tam cytowana.

${ }_{10}$ J. Barta, R. Markiewicz, Ochrona dóbr osobistych w zakresie twórczości naukowej $i$ artystycznej, w: Dobra osobiste $i$ ich ochrona $w$ polskim prawie cywilnym, Wrocław-Warszawa-Kraków-Gdańsk-Łódź 1986, s. 148.

${ }^{11}$ Ustawa z 4 lutego 1994 r. o prawie autorskim i prawach pokrewnych, t.jedn.: Dz. U. 2006, Nr 90, poz. 631 ze zm. (dalej jako: pr.aut.). 
wach autorskich, wobec tego jako przykład wybrane zostało „prawo do autorstwa utworu".

W literaturze polskiej pojęcie autorstwa jest sporne ${ }^{12}$, a próby wyjaśniania istoty „prawa do autorstwa utworu” nie daja jednoznacznej odpowiedzi na temat konstrukcji tego prawa ${ }^{13}$. Problem braku jednoznacznego wyjaśnienia konstrukcji „prawa do autorstwa utworu” tkwi, jak się wydaje, w postrzeganiu go jako prawa podmiotowego. Warto zatem podjać próbę innego uzasadnienia ochrony autorstwa utworu. To uzasadnienie wymaga jednak rozważenia zagadnień ogólnych w stosunku do kwestii autorstwa utworu.

II. Nie ulega wątpliwości, że na gruncie prawa cywilnego „ochrona prawna osoby i jej interesów nie jest realizowana wyłącznie przez przyznanie praw podmiotowych, ale polega także na normatywnym uznaniu wartości i interesów indywidualnych oraz ustanowieniu wzorców postępowania, regulujących współżycie społeczne"14. Ten drugi rodzaj ochrony Bogusław Gawlik proponuje nazwać „ochroną instytucjonalną, ponieważ w procesie stanowienia norm służących zabezpieczeniu prawnie uznanych wartości i interesów bierze pod uwagę uczestnictwo i status człowieka w grupach społecznych oraz uwzględnia ustalone i sankcjonowane społecznie, powtarzalne sposoby zachowania skierowane ku innym, określane w naukach społecznych jako „instytucje” lub „zinstytucjonalizowane wzory zachowań"15.

Gawlik kwestionuje zasadność oparcia ochrony dóbr osobistych z art. 23 k.c. na konstrukcji prawa podmiotowego. Zgadzam się z propozycją autora, aby ochronę atrybutów człowieka (osoby) w postaci jego dóbr osobistych mieszczących się w zakresie art. 23 k.c. uznać za „instytucjonalną ${ }^{16}$. Za odrzuceniem konstrukcji prawa podmiotowego w tym zakresie przemawia przede wszystkim sformułowanie art. 23 k.c., a ponadto sama konstrukcja prawa podmiotowego. Wymaga ona autonomiczności (,zewnętrzności”) chronionego dobra względem podmiotu prawa. Zdaniem Gawlika, dobra osobiste objęte zakresem art. 23 k.c. są „wewnętrznymi” wartościami osoby ${ }^{17}$ (czyli „uprawnionego” w konstrukcji prawa podmiotowego), a więc brakuje im cechy autonomiczności. Dokładna analiza koncepcji Gawlika nie jest w tym miejscu możliwa, wobec tego pozostaje przytoczenie niektórych zawartych w niej argumentów. Zdaniem autora dobra osobiste podlegaja ochronie nie dlatego, że dana osoba przywiązuje do nich subiektywne doniosłe znaczenie, ale dlatego, że porządek prawny uznaje i aprobuje potrzebę ich ochrony ${ }^{18}$. Przy wyróżnieniu takich zobiektywizowanych wartości znaczenie mają nie tylko przepisy prawne, lecz także zasady współżycia społecznego i utrwalone zapatrywania społeczne,

12 Por. M. Jankowska, Autor i prawo do autorstwa, Warszawa 2011, s. 373-379.

13 Ibidem, s. 379-395.

${ }^{14}$ B. Gawlik, Ochrona dóbr osobistych. Sens i nonsens tzw. praw podmiotowych osobistych, „Zeszyty Naukowe Uniwersytetu Jagiellońskiego. Prace z Wynalazczości i Ochrony Własności Intelektualnej” 1985, z. 41, s. 138.

15 Ibidem.

16 Ibidem, s. 138-140.

17 Ibidem, s. 126-127.

18 Ibidem, s. 139. 
obyczajowe i etyczne. Wyróżnione i uznane wartości są uwarunkowane kulturowo, a zatem przez czynniki obiektywne wobec podmiotów ochrony prawnej. Ochrona dóbr osobistych jest skierowana przeciwko bezprawnym ich naruszeniom. Jednakże w przypadku naruszenia większości tych dóbr występuje konflikt wartości i interesów, które zasługują na ochronę prawną ale nie mogą być jednocześnie realizowane. Dlatego pojawia się potrzeba porównania względnej wagi konkurencyjnych wartości i interesów oraz ustalenia reguł preferencyjnych określających zakres ich ochrony. Wobec tego tworzy się normy, które zakazują lub nakazują określone postępowanie jednych osób względem innych osób i w ten sposób wyznaczaja granice ochrony ich dóbr osobistych. Ten, kto przestrzega wspomnianych zakazów i nakazów, działa w sposób dozwolony, nawet gdy narusza cudze dobra osobiste. Dopiero po bezprawnym naruszeniu granic ochrony dóbr osobistych „pojawiają się" roszczenia skierowane przeciwko sprawcy takiego naruszenia, ale przyznanie tych roszczeń nie uzasadnia wniosku, że wypływaja one $\mathrm{z}$ naruszenia przysługujacych pokrzywdzonemu bezwzględnych praw podmiotowych ${ }^{19}$. Trafny wydaje się także pogląd Gawlika, że przyczyną powszechnej akceptacji koncepcji tzw. podmiotowych praw osobistych jest funkcja ideologiczna tej koncepcji ${ }^{20}$. Rzeczywiście, na gruncie prawa prywatnego, którym jest prawo cywilne, lepiej przyjmowane sa w świadomości społecznej wypowiedzi przedstawicieli doktryny formułowane w języku praw podmiotowych przysługujących każdemu, niż wypowiedzi ujmowane w języku zakazów i nakazów postępowania dotyczących „wszystkich wobec wszystkich".

Za koncepcją Bogusława Gawlika opowiedziała się Monika Czajkowska-Dabrowska, która zarzuciła także ustawodawcy brak konsekwencji w realizacji koncepcji ochrony praw podmiotowych osobistych ${ }^{21}$. Z kolei Bogudar Kordasiewicz odrzuca wykorzystanie konstrukcji prawa podmiotowego w sytuacji braku możliwości teoretycznego, abstrakcyjnego wyznaczenia sfery chronionej ${ }^{22}$. Uważa, że w koncepcji instytucjonalnej ochrony zgłoszonej przez Gawlika też nie da się wyznaczyć w sposób abstrakcyjny zinstytucjonalizowanych wzorców zachowań. Stwierdza, że art. 23 k.c. zawiera w istocie klauzulę generalna, która daje sędziemu swobodę określania zakresu dóbr i praw osobistych oraz oceny bezprawności naruszenia ${ }^{23}$. Takie stanowisko zajmuje również Magdalena Lijowska ${ }^{24}$.

O ile sformułowanie art. 23 k.c. ułatwia uzasadnienie koncepcji instytucjonalnej ochrony dóbr osobistych prawa powszechnego, o tyle brzmienie art. 16 pr.aut. utrudnia próbę „przeszczepienia” tej koncepcji na grunt prawa autorskiego. Redakcja tego przepisu jest wysoce niedoskonała, co powoduje,

19 Ibidem, s. $138-140$.

${ }^{20}$ Ibidem, s. 140

21 M. Czajkowska-Dąbrowska, Kilka uwag na temat praw podmiotowych osobistych, „Państwo i Prawo" 42, 1987, z. 7, s. 38.

${ }^{22}$ B. Kordasiewicz, Jednostka wobec środków masowego przekazu, Wrocław-Warszawa-Kraków 1991, s. 159.

23 Ibidem, s. 164.

${ }^{24}$ M. Lijowska, op. cit., s. 793. 
że może być on i jest różnie interpretowany ${ }^{25}$. Nie operuje bowiem pojęciem autorskich dóbr osobistych, lecz określeniem „autorskie prawa osobiste”, które mają chronić więź twórcy z utworem, a w szczególności (i między innymi) „prawo do autorstwa utworu”. Normatywny chaos terminologiczny powoduje konieczność odrzucenia wykładni literalnej art. 16 pr.aut. W literaturze przyjmuje się, że przedmiotem autorskich praw osobistych w rozumieniu art. 16 pr.aut. są autorskie dobra osobiste, gdyż pojęcie „więzi” nie wypiera pojęcia tych dóbr osobistych. „Więź” z założenia ma uzasadniać, dlaczego twórca może dochodzić ochrony swoich dóbr osobistych, chociaż naruszono obiekt odrębny od jego osoby ${ }^{26}$. Tę więź uznaje się za synonim autorstwa, które jest podstawa i motywem przyznania twórcy praw mających chronić jego autorskie dobra osobiste. W myśl prezentowanego poglądu autorstwo nie jest ani dobrem, ani prawem osobistości twórcy, lecz stanowi oparcie dla teoretycznej konstrukcji tych wartości. Utożsamianie „więzi” z „autorstwem” pozwala, według tego poglądu, nadać sens art. 16 pr.aut. ${ }^{27}$

Jeżeli autorstwo utworu, czyli „ojcostwo” utworu, ma być podstawą istnienia dóbr i praw autorskich osobistych, to konstruowanie odrębnego prawa do autorstwa utworu wydaje się zbędne. Ten pogląd jest jednak odosobniony. Konstruowanie „prawa do autorstwa” nie ogranicza się do prawa autorskiego. Prawo własności przemysłowej ${ }^{28}$ stanowi bowiem podstawę kreowania w literaturze prawa do autorstwa ${ }^{29}$, natomiast art. 23 k.c. uznaje się za ewentualna podstawę prawa do autorstwa twórczego wytworu niebędącego utworem ${ }^{30}$.

Wydaje się, że praktyka (obrót) wymusza potrzebę odgraniczenia autorskich dóbr osobistych od pojęcia dóbr osobistych prawa powszechnego, a także konieczność nowego spojrzenia na autorskie prawa osobiste. Zjawisko komercjalizacji autorskich praw osobistych toruje droge poglądowi, że ich przedmiotem nie jest już osobowość twórcy, a więc to nie ona stanowi uzasadnienie ochrony jego niematerialnych interesów ${ }^{31}$. Decydujace znaczenie dla tej ochrony zaczyna mieć sam status bycia twórca, którego głównym elementem jest więź łącząca go z utworem. Ta więź stanowi uzasadnienie przyznania twórcy prawa autorskiego oraz gwarantuje ochronę jego słusznych interesów, także niematerialnych. W tej tendencji autorskie prawa osobiste postrzegane sa jako element systemu, który ma zapewnić autorom (twórcom) należytą ochronę ${ }^{32}$.

III. „Więź twórcy z utworem” jest specyficznym pojęciem prawa autorskiego. Powszechne prawo cywilne z zasady nie chroni więzi niematerialnych (emocjonalnych, sentymentalnych czy intelektualnych) osoby (podmiotu prawa)

${ }_{25}$ Por. np. J. Mazurkiewicz, Non omnis moriar. Ochrona dóbr osobistych zmartego $w$ prawie polskim, Wrocław 2010, s. 102-103; E. Wojnicka, B. Giesen, w: System, t. 13, s. 286-288.

${ }^{26}$ E. Wojnicka, B. Giesen, w: System, t. 13, s. 287.

${ }^{27}$ Ibidem.

${ }^{28}$ Ustawa z 30 czerwca 2000 r. - Prawo własności przemysłowej, t.jedn.: Dz. U. 2013, poz. 1410 .

${ }^{29}$ J. Szwaja, Prawa osobiste wynalazców w nowej ustawie - Prawo własności przemystowej, w: Zagadnienia prawa własności intelektualnej (Zeszyty Naukowe Uniwersytetu Jagiellońskiego, z. 80), Kraków 2002, s. 234.

${ }^{30}$ Por. M. Jankowska, op. cit., s. 396-411.

${ }^{31}$ E. Wojnicka, B. Giesen, w: System, t. 13, s. 284.

${ }^{32}$ Por. ibidem. 
z przedmiotami zewnętrznymi wobec niej ${ }^{33}$. Jak już wspomniano, utożsamianie „więzi” z „,autorstwem” ma nadać sens art. 16 pr.aut. Przyjęcie tego poglądu ułatwia odpowiedź na pytanie, czym jest autorstwo ${ }^{34}$, ale nie przesądza, że ta odpowiedź jest trafna.

Wydaje się, że autorstwo (pierwotne) jest stanem powstałym w wyniku podjęcia aktu tworzenia. Ten stan uzasadnia więź między twórcą a jego utworem. Utwór nosi piętno intelektualnej więzi z twórca, ale jest dobrem odrębnym od jego osoby. Prawo autorskie chroni ten stan (a więc także niematerialna więź między twórca a utworem), ponieważ w cywilizacji, do której należymy, ten stan „sam w sobie” jest wartością niematerialna, akceptowaną i uznana powszechnie przez społeczeństwo, a następnie uznaną za godną ochrony przez ustawodawcę. „Uznanie tej wartości” jest efektem procesu trwającego kilkaset lat, o czym świadczy geneza pojęcia autorskich praw osobistych ${ }^{35}$. Powszechnie akceptowane wartości kształtują się stopniowo i stopniowo ulegają zmianom. Niektóre z nich uznawane zostają za „wartości same w sobie” i „wieczne”, co powoduje, że podlegaja prawnej ochronie nawet wówczas, gdy nie istnieje podmiot, z którym były pierwotnie związane. Taką wartością wydaje się stan autorstwa utworu, który w sposób bardziej precyzyjny oddaje pojęcie statusu twórcy. Ochrona prawna „statusu twórcy utworu” może trwać nawet po śmierci twórcy. Tego rodzaju ochrona nie może być jednak realizowana w ramach konstrukcji prawa podmiotowego, którego niezbędnym elementem jest istnienie podmiotu prawa. Może ją uzasadniać wyżej omawiana, zgłoszona przez Gawlika, koncepcja ochrony instytucjonalnej.

Nie ulega wątpliwości, że „status twórcy” według prawa autorskiego przysługuje tylko człowiekowi i także wówczas, gdy nie jest już osobą fizyczną ${ }^{36}$ w rozumieniu powszechnego prawa cywilnego. Niematerialny status twórcy nie jest dobrem osobistym mieszczącym się w zakresie art. 23 k.c. Ten status jest niematerialną wartością samoistna chronioną prawem autorskim. Wartość chroniona (dobro chronione) i prawo chronione (prawo zasługujące na ochronę) to różne kategorie prawne. Wydaje się, że prawo chronione jest także wartością chroniona, ale nie każda wartość chroniona jest prawem chronionym. Ochronie może podlegać samo dobro (wartość) albo prawo przysługujace ze względu na jakieśs dobro.

IV. Zajęcie stanowiska, że autorskie dobra osobiste są dobrami osobistymi w rozumieniu art. 23 k.c. i sa chronione podmiotowymi, autorskimi prawami osobistymi o charakterze bezwzględnym, powoduje, iż te dobra autorskie i przysługujące ze względu na te dobra podmiotowe prawa osobiste powinny wygasnaćc z chwilą śmierci twórcy. Pogląd o wygasaniu podmiotowych praw osobistych osoby fizycznej z chwila jej śmierci jest powszechny na gruncie pra-

\footnotetext{
${ }^{33}$ A. Wojciechowska, Czy autorskie dobra osobiste sq dobrami osobistymi prawa cywilnego?, „Kwartalnik Prawa Prywatnego” 3, 1994, z. 3, s. 380.

${ }^{34} \mathrm{Na}$ temat tego pojęcia zob. np. M. Jankowska, op. cit., s. 373-379.

35 E. Wojnicka, B. Giesen, w: System, t. 13, s. 274 i n.

${ }^{36}$ Pomijam tu problem ewentualnego uznania prawa do autorstwa osób prawnych czy jednostek organizacyjnych tzw. niepełnych (ułomnych, ustawowych) osób prawnych. Tego rodzaju podmioty mogą być ewentualnie uznane za autora, ale nie za twórcę.
} 
wa cywilnego. Zastosowanie konstrukcji prawa podmiotowego wiąże się bowiem $\mathrm{z}$ istnieniem podmiotu tego prawa, brak podmiotu przesądza o braku prawa podmiotowego. Tezy, że może istnieć prawo podmiotowe osobiste bez podmiotu prawa, nie da się obronić. Jednakże prawo autorskie, w szczególności art. 16 i art. 78 ust. 2-4 pr.aut., nawiązują do pojęcia autorskich praw osobistych i z przytoczonych przepisów wynika, że te prawa osobiste „są wieczne" i nie wygasaja z chwilą śmierci twórcy. Jaki wobec tego jest charakter tych praw i czy w ogóle są to prawa? Odpowiedź muszą poprzedzić rozważania o charakterze systemowym.

W polskim systemie prawnym prawo na dobrach niematerialnych (prawo własności intelektualnej ${ }^{37}$, w tym prawo autorskie, uznawane jest za dział prawa cywilnego. Niektórzy autorzy zaliczają prawo autorskie i prawo własności przemysłowej do odrębnych, kompleksowych działów prawa cywilnego ${ }^{38}$. Twierdzi się, że ten dział prawa cywilnego (prawo własności intelektualnej) nastawiony jest na ochronę rezultatów myśli ludzkiej ujmowanych jako dobra niewymierne przestrzennie (w przeciwieństwie do rzeczy). Podstawą wyodrębnienia wspomnianego działu prawa cywilnego jest zatem jego przedmiot ${ }^{39}$. $\mathrm{Z}$ przedstawionych wyżej wypowiedzi wynika, że prawo autorskie w znaczeniu przedmiotowym chroni dobra niematerialne w postaci rezultatów myśli ludzkiej. Biorąc jednak pod uwagę art. 16 pr.aut. i ograniczając rozważania do sfery niematerialnej związanej z twórca, rodzi się wątpliwość, czy ochronie na gruncie prawa autorskiego podlega rezultat myśli ludzkiej (utwór), autorskie dobra osobiste, autorskie prawa osobiste czy jakaś inna wartość niematerialna.

Przynależność prawa autorskiego do gałęzi prawa cywilnego nie powinna stanowić przeszkody w rozwoju specyficznych instytucji pierwszego z wymienionych praw. Zasada jedności prawa cywilnego (art. 1 k.c.) nie oznacza bowiem niedopuszczalności odmiennych regulacji w ustawach szczególnych instytucji, których konstrukcja ogólna znana jest Kodeksowi cywilnemu, ale nie nadaje się do stosowania do tej instytucji szczególnej. Jednakże twierdzi się, że doniosłość tego aktu normatywnego powoduje powszechne oddziaływanie podstawowych konstrukcji i wypracowanych na jego tle koncepcji na całość prawa prywatnego ${ }^{40}$. Te wypracowane na gruncie Kodeksu cywilnego koncepcje i konstrukcje z jednej strony ułatwiają stosowanie cywilnoprawnych przepisów pozakodeksowych, ale z drugiej - są przyczyną sporów na temat charakteru specyficznych instytucji uregulowanych poza tym Kodeksem, podobnych do tych kodeksowych.

Kodeksowe koncepcje i konstrukcje dotyczące dóbr osobistych i podmiotowych praw osobistych sa przyczyną sporów na temat autorskich dóbr osobistych i konstrukcji autorskich praw osobistych. Można powiedzieć, że utrud-

${ }_{37}$ Z. Radwański, Prawo cywilne. Część ogólna, Warszawa 2009, s. 14-15, chociaż pojęcie dóbr niematerialnych jest szersze od dóbr własności intelektualnej, a wobec tego pojęcie prawa na dobrach niematerialnych jest szersze od prawa własności intelektualnej w znaczeniu przedmiotowym.

38 M. Safjan, w: System, t. 1, s. 62.

${ }^{39}$ Z. Radwański, A. Olejniczak, Zobowiazania-część ogólna, Warszawa 2014, s. 2.

${ }^{40}$ M. Safjan, w: System, t. 1, s. 69. 
niaja one „oderwanie” konstrukcji prawa autorskiego od konstrukcji prawa cywilnego powszechnego, a budowanie samodzielnych i specyficznych konstrukcji prawa autorskiego niekiedy prowadzi do powstania sprzeczności, których nie da się usunąć bez „weryfikacji” tych specyficznych konstrukcji.

V. Kodeks cywilny realizuje zasadę, że określone prawa podmiotowe i wynikajace z nich uprawnienia przysługuja podmiotom prawa cywilnego. Tymi podmiotami „w zakresie stosunków cywilnoprawnych” moga być tylko osoby fizyczne, osoby prawne oraz tzw. niepełne osoby prawne (art. $33^{1}$ k.c.). Co prawda Księga pierwsza tytuł II dział I k.c. nosi tytuł „Osoby fizyczne”, lecz jego art. 8 § 1 stanowi, że „każdy człowiek od chwili urodzenia ma zdolność prawną" i nie ma przepisu, który wyraźnie stanowiłby, że tę zdolność traci $\mathrm{z}$ chwilą śmierci. Stanowisko doktryny o charakterze powszechnym przesądza jednak, że z chwilą śmierci człowiek traci tę zdolność, a zatem przestaje być osoba fizyczną ${ }^{41}$.

Warto rozważyć, czy regulacje powszechnego prawa cywilnego dotyczące praw, dóbr i wartości związanych z człowiekiem odnoszą się tylko do osoby fizycznej, a więc do podmiotu posiadającego zdolność prawna, czy też moga uwzględniać jego status przed urodzeniem się i po śmierci. Wykładnia literalna (wobec jej jednoznaczności nie trzeba sięgać do innej) art. $8 \S 1$ k.c. przesadza, że ten przepis nie określa, kto jest człowiekiem, tylko kto jest osobą fizyczną. Regulacja w prawie cywilnym szczególnej, warunkowej zdolności prawnej nasciturusa nie budzi wątpliwości.

Według Kodeksu cywilnego osobą fizyczna jest zatem człowiek plus ży$\mathrm{cie}^{42}$, ale ta regulacja nie przesądza, że brak życia decyduje o utracie statusu człowieka w rozumieniu prawa cywilnego. Fakt śmierci kreuje bowiem status człowieka zmarłego. Z art. 922 k.c. wynika, że z chwilą śmierci człowieka jego prawa i obowiązki majątkowe przechodzą na spadkobierców, a prawa i obowiązki zmarłego ściśle związane z jego osobą nie należą do spadku. Ten przepis przesądza jedynie, że prawa i obowiązki ściśle związane z osobą zmarłego nie podlegają dziedziczeniu, ale nie przesądza o ich wygaśnięciu. $\mathrm{O}$ tym wygaśnięciu przesądzają poglądy przedstawicieli nauki prawa akceptowane przez orzecznictwo. Ustawodawca nie przesądza o takim skutku w sposób generalny (ogólny).

Człowieka żyjącego nie można jednak postrzegać na gruncie prawa cywilnego jako wyłącznie „posiadającego prawa i obowiązki”. Człowiek ma przede wszystkim zagwarantowaną sferę wolności, w która nie ingeruje prawo cywilne, chyba że swoim postępowaniem naruszy jakąś obowiązującą normę prawna. Efektem tego wolnościowego postępowania może być także powstanie różnego rodzaju dóbr lub nabycie statusu, które to wartości sa przedmiotem zainteresowania prawa cywilnego. Nie ulega wątpliwości, że w ten sposób powstają również niematerialne więzi, które nadają człowiekowi określony status i ten niematerialny status człowieka nie wygasa $\mathrm{z}$ chwila jego śmierci. Świadczy o tym choćby status człowieka wynikający z pokrewieństwa, które-

${ }^{41}$ M. Pazdan, w: System, t. 1, s. 952.

${ }^{42}$ Ibidem, s. 956. 
go ustalenie i skutki regulują przepisy Kodeksu rodzinnego i opiekuńczego ${ }^{43}$, oraz status twórcy utworu w rozumieniu prawa autorskiego. Prawo rodzinne jest działem prawa cywilnego, podobnie jak działem tej gałęzi prawa jest prawo własności intelektualnej, w tym prawo autorskie. Wymienione działy prawa cywilnego charakteryzuja się pewną specyfiką także w zakresie podmiotowości, jeżeli na prawo cywilne spojrzeć z punktu widzenia tego kryterium. Otóż podmiotami praw rodzinnych są tylko osoby fizyczne, a ponadto w prawie rodzinnym dominuja prawa niemajątkowe ${ }^{44}$. Z powodu więzi pokrewieństwa podmioty tego prawa uzyskują status np. ojca, matki, syna, córki itp., który trwa i podlega ochronie nawet po śmierci osoby fizycznej posiadającej taki status. Podmiotami prawa autorskiego sa generalnie podmioty prawa cywilnego, ale status twórcy (współtwórcy) utworu posiada tylko człowiek żyjący (osoba fizyczna) lub zmarły. Tylko on posiada status twórcy (współtwórcy), natomiast status autora mogą posiadać także inne podmioty ${ }^{45}$. Status „ojcostwa” utworu, tak jak status ojcostwa naturalnego, nie wygasa z chwila śmierci człowieka. Ucieleśniają one wartości niematerialne, którymi sa pokrewieństwo naturalne lub intelektualne, a tego rodzaju wartości niematerialne chronia przepisy prawne także po śmierci człowieka. Status „ojcostwa” naturalnego lub intelektualnego nie jest jednak prawem podmiotowym, jest wartością niematerialna (dobrem niematerialnym), której granice ochrony wyznacza prawo przedmiotowe. Normy prawa przedmiotowego wskazują również podmioty uprawnione do korzystania z instrumentów służących prawnej ochronie „wartości niematerialnej ojcostwa". Nie ma zatem przeszkód, aby uprawnienie do korzystania z instrumentów ochrony wspomnianych wartości przyznać „osobom trzecim”.

$\mathrm{Na}$ niektóre wartości związane z człowiekiem, chronione prawem cywilnym warto spojrzeć przez pryzmat człowieka, a nie tylko osoby fizycznej będącej podmiotem prawa cywilnego. Sa bowiem pośród nich wartości, których nie limituje życie człowieka. Należy do nich status twórcy utworu w rozumieniu prawa autorskiego.

VI. Ochrona autorskich dóbr osobistych nie powinna być realizowana w ramach konstrukcji praw podmiotowych bezwzględnych. Jak już wspomniano, prawo podmiotowe nie może istnieć bez podmiotu, a ochrona autorskich dóbr osobistych trwa także po śmierci twórcy ${ }^{46}$. Ponadto konstrukcja tego prawa jest przydatna do ochrony sfery majątkowej podmiotów prawa cywilnego. $\mathrm{Na}$ przykład prawo własności dotyczy rzeczy, ale ustawodawca chroni nie rzecz, lecz podmiotowe prawo własności (art. 140 k.c.). Instrumenty ochronne dotycza tego prawa (art. 222 i n. k.c.). Z kolei posiadanie nie jest prawem podmiotowym tylko stanem faktycznym, a prawo cywilne chroni ten stan (art. 336 i n. k.c.). Konstrukcji praw podmiotowych nie wykorzystuje się przy ochronie deliktowej (art. 415 i n. k.c.). Mimo tego faktu dobra osobiste są także chronione w re-

${ }^{43}$ Ustawa z 25 lutego 1964 r. - Kodeks rodzinny i opiekuńczy, t.jedn.: Dz. U. 2012, poz. 788 ze zm.

${ }^{44}$ M. Pyziak-Szafnicka, w: System, t. 1, s. 721.

${ }^{45}$ Np. R. Golat, Prawo autorskie i prawa pokrewne, Warszawa 2008, s. 107.

${ }^{46}$ Zob. J. Mazurkiewicz, op. cit., s. 81 i n. 
żimie deliktowym (np. art. 448 k.c.). Posłużenie się konstrukcją prawa podmiotowego wymaga określenia sfery chronionej oraz kryteriów jej naruszenia, co jest szczególnie istotne przy podmiotowych prawach bezwzględnych. Wydaje się, że ze względu na możliwość odpłatnego i nieodpłatnego korzystania z utworu oraz rozwój nowoczesnych sposobów korzystania z niego, ustalenie takiej sfery i kryteriów ochrony niematerialnej wartości „więzi twórcy z utworem”, tkwiącej w tym utworze, za pomoca podmiotowego, bezwzględnego prawa autorskiego nie jest możliwe.

Wobec przedstawionych argumentów trudno jest ustalić sferę i kryteria ochrony w wymienionym w art. 16 pr.aut. „prawie do autorstwa utworu”. W ogóle trudno jest wywnioskować, co w tym przepisie jest przedmiotem ochrony i jaka jest konstrukcja tej ochrony. Jeżeli przyjmiemy, że w tym przepisie wymienione sa autorskie prawa osobiste będące podmiotowymi, niezbywalnymi prawami bezwzględnymi, które chronią „nieograniczoną w czasie i niepodlegającą zrzeczeniu się lub zbyciu więź twórcy z utworem" (czyli autorstwo), to czym w takim razie jest wymienione odrębnie w tym przepisie „prawo do autorstwa utworu”? Prawo podmiotowe nie może chronić „autorstwa" po śmierci twórcy, a więc cel ochrony deklarowanej w art. 16 pr.aut. jest z góry nieosiagalny. Podmiotowe prawo osobiste do autorstwa utworu także nie może zapewnić tej ochrony, a ponadto prawo przedmiotowe chroni prawa podmiotowe, z kolei funkcja praw podmiotowych nie sprowadza się do ochrony przedmiotu, którego dotyczą (ze względu na który zostały ukształtowane).

W literaturze wyodrębnia się dwie postacie prawa do autorstwa utworu: negatywną i pozytywną ${ }^{47}$. Negatywna ma wyrażać się w skutecznym względem wszystkich zakazie przywłaszczania autorstwa. Twierdzi się, że autor może żądać, aby nikt nie oznaczał jego dzieła własnym nazwiskiem lub pseudonimem $^{48}$. Ale prawo do oznaczenia utworu swoim nazwiskiem lub pseudonimem albo do udostępniania go anonimowo jest wymienione w art. 16 pkt 2 pr.aut. Wobec tego wspomniane wyżej żądanie autora nie powinno dotyczyć treści prawa do autorstwa utworu, lecz treści prawa wymienionego w art. 16 pkt 2 pr.aut. Z kolei pozytywna postać prawa do autorstwa ma polegać na obciążeniu niektórych osób obowiązkiem wymienienia nazwiska i pseudonimu jego autora w sposób zwyczajowo przyjęty, a od twórcy wymaga wskazania autorstwa i źródła cytatów lub innych zapożyczeń oraz pierwowzoru opracowania ${ }^{49}$. Ta treść podmiotowego prawa do autorstwa utworu (art. 16 pkt 1 pr.aut.) powinna dotyczyć raczej prawa ujętego w art. 16 pkt 2 pr.aut. W każdym razie ujmowania prawa do autorstwa w szerszym i węższym znaczeniu ${ }^{50}$ nie pozwala ustalić jednoznacznie, co jest treścią podmiotowego prawa do autorstwa utworu mającego mieć charakter prawa podmiotowego bezwzględnego. Ponadto zjawisko traktowania dóbr intelektualnych jako towarów jest już faktem ${ }^{51}$. Ustalenie dzieła, w szczególności wówczas gdy zostało upublicznione, powodu-

\footnotetext{
${ }^{47}$ E. Wojnicka, B. Giesen, w: System, t. 13, s. 305 oraz literatura tam cytowana.

48 Ibidem.

49 Ibidem.

50 M. Jankowska, op. cit., s. 379 oraz literatura tam cytowana.

${ }^{51}$ A. Wojciechowska, op. cit., s. 383.
} 
je, że utwór odrywa się od twórcy i staje się obiektem zainteresowania uczestników rynku. W tej sytuacji ustalenie sfery ochrony autorstwa jako wartości niematerialnej chronionej za pomocą prawa podmiotowego nie wydaje się możliwe. Niematerialne wartości ucieleśnione w utworze, w tym jego autorstwo, konfrontowane są bowiem z innymi wartościami oraz interesami uczestników rynku korzystających w dozwolony sposób z utworu. Nie każdy przypadek naruszenia autorstwa będzie uznany za bezprawny. Brak precyzyjnego określenia sfery chronionej osobistym prawem do autorstwa może być, a nawet jest utrudnieniem w obrocie autorskimi prawami majątkowymi. Coraz częściej twórcy świadomie przypisują swoje dzieło innej osobie (ghostwriting), co jest praktyką kontrowersyjna, ale świadcząca o zjawisku materialnego stosunku twórców do swojego niematerialnego autorstwa. Twórca, mimo posiadania bezwzględnych praw autorskich osobistych, staje się stroną „słabszą” w relacjach z przedsiębiorcami (profesjonalistami). Te okoliczności także przesądzają o potrzebie weryfikacji koncepcji ochrony autorstwa za pomocą konstrukcji osobistego prawa podmiotowego niezbywalnego o charakterze bezwzględnym.

Wydaje się, że do ochrony niematerialnego statusu twórcy utworu (autorstwa) w rozumieniu prawa autorskiego można de lege ferenda wykorzystać koncepcję Gawlika dotyczącą ochrony instytucjonalnej dóbr osobistych, jednak z modyfikacjac. Warto wykorzystać ją do ochrony osobistego dobra autorskiego, za które uznać należy niematerialny status twórcy - człowieka, a nie tylko twórcy - osoby fizycznej. Ten postulat mógłby zostać rozważony przy okazji zmiany art. 16 pr.aut., a potrzeba zmiany tego przepisu nie powinna budzić wątpliwości.

prof. dr hab. Bogustawa Gnela

Uniwersytet Ekonomiczny w Krakowie

gnelab@uek.krakow.pl

\section{SOME REMARKS ON THE SPECIFIC CHARACTER OF AUTHOR'S PERSONAL INTERESTS AND THE CONCEPT OF THEIR PROTECTION}

(ON THE EXAMPLE OF THE RIGHT TO AUTHORSHIP)

\section{Sum mary}

The article advocates against the concept of protection of civil personal rights using an absolute subjective right and affirms the concept of so-called institutional protection of personal rights. It has been claimed, based on the 'right to authorship' example, that the right to authorship should constitute the main personal right protected by copyright law rather than be protected by subjective moral rights of the author. 'The right to authorship of the work' is not a subjective right, but it is (in fact) an intangible right to authorship, protected by copyright law. 
